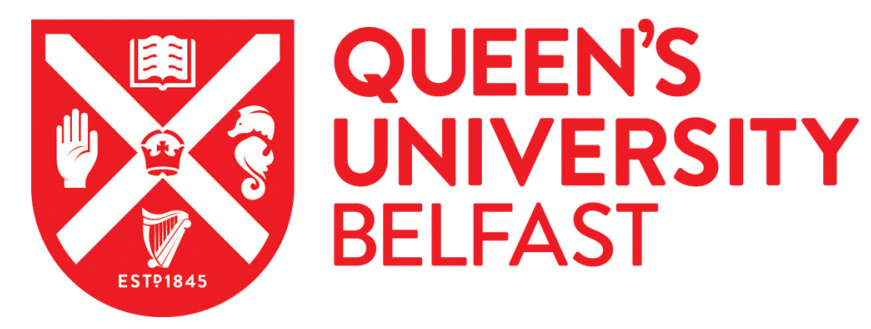

\title{
Drying and Denaturation Kinetics of Beta-Lactoglobulin during Convective Drying
}

Haque, M. A., Oliver, M. M. H., Putranto, A., \& Adhikari, B. (2018). Drying and Denaturation Kinetics of BetaLactoglobulin during Convective Drying. Journal of Food Engineering.

https://doi.org/10.1016/j.jfoodeng.2018.05.018

Published in:

Journal of Food Engineering

Document Version:

Peer reviewed version

Queen's University Belfast - Research Portal:

Link to publication record in Queen's University Belfast Research Portal

Publisher rights

Copyright 2018 Elsevier

This manuscript is distributed under a Creative Commons Attribution-NonCommercial-NoDerivs License

(https://creativecommons.org/licenses/by-nc-nd/4.0/), which permits distribution and reproduction for non-commercial purposes, provided the author and source are cited.

\section{General rights}

Copyright for the publications made accessible via the Queen's University Belfast Research Portal is retained by the author(s) and / or other copyright owners and it is a condition of accessing these publications that users recognise and abide by the legal requirements associated with these rights.

Take down policy

The Research Portal is Queen's institutional repository that provides access to Queen's research output. Every effort has been made to ensure that content in the Research Portal does not infringe any person's rights, or applicable UK laws. If you discover content in the Research Portal that you believe breaches copyright or violates any law, please contact openaccess@qub.ac.uk. 
2 M. Amdadul Haque ${ }^{1 *}$, Md. Moinul Hosain Oliver $^{2}$, Aditya Putranto $^{3}$, Benu Adhikari ${ }^{4}$

3 'Department of Agro-processing, Bangabandhu Sheikh Mujibur Rahman Agricultural

4 University (BSMRAU), Gazipur1706, Bangladesh

$5 \quad{ }^{2}$ Department of Agricultural Engineering, BSMRAU, Gazipur1706, Bangladesh

$6 \quad{ }^{3}$ School of Chemistry and Chemical Engineering, Queen's University Belfast, David Keir

7 Building, 39-123 Stranmilis Road, Belfast BT9 5AG, United Kingdom

$8 \quad{ }^{4}$ School of Science, RMIT University, Melbourne, VIC 3083, Australia

9

10

*Corresponding author: +88 01934 499867; Email: $\underline{\text { amdad115@gmail.com }}$ 
ABSTRACT

Beta-Lactoglobulin $(\beta-\mathrm{Lg})$ is the largest protein fraction of whey proteins comprising more than $65 \%$. Being the major fraction, it determines many of the unique properties of whey proteins. Thus, the denaturation of $\beta-\mathrm{Lg}$ during drying can limit the application of whey proteins as ingredient. This study was carried out to measure and predict the drying and denaturation kinetics of $\beta-\mathrm{Lg}$ during drying at droplet level in a convective drying environment. The moisture content and temperature scenarios during the drying process were predicted using reaction engineering approach (REA)-based model. The REA-predictions were coupled with the first order reaction kinetics to predict the denaturation kinetics. Single droplets of $\beta-\mathrm{Lg}$ $(10 \% \mathrm{w} / \mathrm{v} ; 1.5 \pm 0.1 \mathrm{~mm}$ initial diameter $)$ were used throughout drying experiments carried out at two temperatures $\left(65^{\circ} \mathrm{C}\right.$ and $\left.80{ }^{\circ} \mathrm{C}\right)$ at a constant air velocity $(0.5 \mathrm{~m} / \mathrm{s})$ for 10 minutes. There was a good agreement between the experimental data and the REA predictions. The model predictions fitted the experimental data with $\pm 5.70 \%$ and $\pm 3.50 \%$ error for moisture-time and temperature-time profiles, respectively. A combination of the REA-based model with first order kinetics model was also successful in predicting the denaturation kinetics.

27 Keywords: Beta-Lactoglobulin, denaturation kinetics, drying kinetics, single droplet drying, reaction engineering approach (REA). 
Whey proteins are widely used in food product formulations due to their nutritional and functional properties. Beta-Lactoglobulin $(\beta-\mathrm{Lg})$ is one of the major components of whey proteins and it is largely responsible for imparting the unique gelation, foaming and emulsification properties to whey proteins. In addition, $\beta$-Lg also has very good flavour binding properties which makes it suitable ingredient in many food and beverage products (Jime'nezCastano et al., 2005). Furthermore, $\beta$-Lg is a good source of amino acids and has high solubility and clarity over a broad $\mathrm{pH}$ range. These properties have enabled this protein to use as an active agent in various protein-fortified beverages, such as fruit juices and sports drinks (Ikeuchi, et al., 2008; Chatterton et al., 2006). An additional benefit associated with $\beta$ - $\mathrm{Lg}$ is that it exhibits mild antioxidant activity which is reportedly due to the free thiol group present in the structure (Shpigelman et al., 2010). The molecular weight of $\beta-\mathrm{Lg}$ is $18.4 \mathrm{kDa}$ and its structure contains 2 disulphide bridges and one free cysteine residue.

In our previous study of isothermal heat treatment (in aqueous medium) and convective air drying of whey protein isolate (WPI), we showed that $\beta$-Lg was more susceptible to heating on its molecular composition and structure and the folded polypeptide chains perform protein's biological functions. External forces such as dehydration stresses can unfold the secondary and higher order structure of proteins and negatively affect their stability, especially in aqueous 
systems. In the case of spray drying, high temperature and interfacial stresses are implicated to the denaturation of proteins (Haque, et al., 2015b). A more scientifically robust way of overcoming this problem is to carefully control the drying parameters during spray drying (Anandharamakrishnan et al., 2007). For this purpose, a clear understanding of the relationship between drying and denaturation kinetics is required. In particular, the changes brought about by the denaturing stresses have to be quantified in order to control the protein denaturation. Despite being major fraction of whey protein, information regarding behaviour or response of $\beta$-Lg molecules under stresses is very limited in the literature.

Spray drying is widely used technique in food and pharmaceutical industry as it is relatively economical compared to freeze drying and also it has considerably high throughput (Chavez \& Ledeboer, 2007; Haque \& Adhikari, 2014). Despite the above mentioned advantages, a suitable technology for measuring drying and denaturation kinetics of protein droplets, in situ, in a spray drying chamber is yet to be developed. Due to the presence of billions of droplets in a spray drying chamber and also due to prevailing complex flow pattern, the relationship between drying and denaturation kinetics of $\beta-\mathrm{Lg}$ in spray drying process is not available. Hence, in absence of the in situ measurement technology, single droplet drying (SDD) of proteins is, so far, the most useful technology to measure both drying and denaturation kinetics at droplet level (Sano \& Keey, 1982; Che et al., 2012; Haque et al., 2016). SDD also enables imaging of the surface topography of a drying droplet and hence enables acquiring the morphological data of drying droplets/particles. Therefore, the drying and denaturation kinetics, and surface morphology of $\beta$-Lg can be measured and interpreted using SDD. In this work, we present the drying and denaturation kinetics and surface morphology of single droplet of aqueous solution of $\beta$ - Lg in particle formation process using SDD. We also present the prediction of the above mentioned data using reaction engineering approach (REA) tools. It is known that the spray drying system operates with two control temperatures; inlet temperature and outlet 
temperature. The outlet temperature is very sensitive to product quality because atomized droplet contains less water toward the end of drying. The hot air comes at direct contact of the moist particles and causes damage to the particles. Hence, the protein powder manufactures as well as researchers are trying to reduce the outlet temperature of the drying chamber (from high temperature i.e. $80^{\circ} \mathrm{C}$ to low temperature i.e. $65^{\circ} \mathrm{C}$ or even lower) for minimal effect on the product. We used these two temperatures $\left(80^{\circ} \mathrm{C}\right.$ and $\left.65^{\circ} \mathrm{C}\right)$ for drying the protein droplets to present a comparative pictures of denaturation of protein both at higher and lower drying temperatures. The findings, presented in this work, will enable the manufacturers to tailor and control the drying parameters to produce structurally intact and minimally denatured $\beta$-Lg powders through spray drying. The REA based modelling approach can also be used for dryer wide simulations by embedding the REA-based modelling into Computational Fluid Dynamics (CFD) environment (Lin \& Chen, 2006; Patel \& Chen, 2005). In this study, the lumped reaction engineering approach (L-REA) is implemented to model the average moisture content during drying.

\section{Experimental Section}

\subsection{Materials}

High purity $(\geq 95 \%) \beta$-Lg was purchased from Sigma-Aldrich (New South Wales, Australia). The acetonitrile and Deuterium oxide $\left(\mathrm{D}_{2} \mathrm{O}\right)$ were also purchased from Sigma-Aldrich (New South Wales, Australia). The trifluoroacetic acid (TFA) was purchased from Fisher Scientific (Victoria, Australia).

\subsection{Methods}




\subsubsection{Single Droplet Drying (SDD)}

The design, working principle and other details of this instrument are provided elsewhere (Adhikari et al., 2007). The aqueous $5 \pm 0.1 \mu \mathrm{L}$ droplets of $\beta-\mathrm{Lg}(10 \% \mathrm{w} / \mathrm{v})$ solution were suspended on the tip of a glass filament of $0.2 \pm 0.01 \mathrm{~mm}$ diameter. The $\beta$-Lg droplets which were suspended to the glass filaments were held inside the drying chamber by using a bored Teflon cylinder. The drying air was allowed to pass through a series of columns containing dried molecular sieves and dried silica gels. This dried air was finally passed through the drying chamber. Two drying temperatures $\left(65^{\circ} \mathrm{C}\right.$ and $\left.80^{\circ} \mathrm{C}\right)$ were used and these temperatures were maintained using a PID controller. The relative humidity values of the drying air were measured by using EL-USB relative humidity data logger (Lascar Electronics, UK), and were found to be $2 \pm 0.5 \%$ at these two drying temperatures. The wet bulb temperatures were $26^{\circ} \mathrm{C}$ and $30^{\circ} \mathrm{C}$ at air temperatures of $65^{\circ} \mathrm{C}$ and $80^{\circ} \mathrm{C}$, respectively. The droplets were dried for $600 \mathrm{~s}$. The droplets were collected at every $100 \mathrm{~s}$ interval in order to measure the denaturation of $\beta-\operatorname{Lg}$ as a function of drying time and temperature. The velocity of air passing through the stationary droplet was maintained at $0.5 \mathrm{~m} / \mathrm{s}$ in all the experiments reported. Loss of mass and temperature history were recorded in a computer. Images of the drying droplets were captured using a digital camera (EOS 60D, Canon, NSW, Australia) at $50 \times$ magnification. The camera was attached to the back of the single droplet drying instrument and abled to focus in the drying chamber.

\subsubsection{Determination of denaturation of $\beta$ - Lg by using reversed phase (RP)-HPLC}

The droplets dried to predetermined time using the SDD instrument were collected carefully in Eppendorf microtubes and diluted to $100 \mu \mathrm{g} / \mathrm{mL}$ with deionized water. The $\mathrm{pH}$ of this solution was then adjusted to 4.6 by adding $0.1 \mathrm{M} \mathrm{HCl}$ that would separate the un-denatured and irreversibly denatured $\beta-\operatorname{Lg}$ (Parris \& Baginski, 1991; Haque et al., 2015). After keeping 
the $\beta$-Lg solution samples at this $\mathrm{pH}$ for 30 minutes, they were centrifuged at $13,000 \mathrm{rpm}$

128

129

130

131

132

133

134

135

136

137

138

139

140

141

$(11,500 \mathrm{~g})$ for 10 minutes. The supernatant was collected and injected onto the reversed-phase column to separate the denatured and un-denatured $\beta-\operatorname{Lg}$ as described previously (Ferreira \& Caçote, 2003). The same amount of $\beta$-Lg solution, without subjecting to the drying was used as a control. The same $\mathrm{pH}$ treatment and centrifugation procedures were followed to this control sample as well. The supernatant of the control samples was also injected in the same way to determine the denatured and un-denatured fractions. A reversed-phase column (Aeris WIDEPORE 3.6 XB-C18, 150×2.1mm, Phenomenex Pty. Ltd., Australia) was used to separate the denatured and un-denatured $\beta-\operatorname{Lg}$ fractions. In these tests a $0.1 \%(\mathrm{v} / \mathrm{v})$ aqueous solution of TFA was used as solvent $\mathrm{A}$ and $0.1 \%$ TFA in $80 \%$ aqueous acetonitrile (v/v) was used as solvent B. The temperature of the column and the flow rate of the solvent were maintained at $40{ }^{\circ} \mathrm{C}$ and $0.5 \mathrm{~mL} / \mathrm{min}$, respectively. The injection volume of the sample was $40 \mu \mathrm{L}$. A UVdetector at wavelength of $215 \mathrm{~nm}$ was used in these tests. The percentage of denatured $\beta$-Lg was calculated using equation (1), as suggested by Parris \& Baginski (1991).

Denatured protein $(\%)=\left(1-\frac{A_{\text {treat }}}{A_{\text {control }}}\right) \times 100$

where

$A_{\text {treat }}=$ area of HPLC peak eluted by dried protein sample

$A_{\text {control }}=$ area of HPLC peak eluted by control protein sample

Each of these experiments was carried out in triplicates and the average values are reported.

\subsubsection{Acquiring and analysis the IR spectra}

For structural observation the $\beta$-Lg samples were scanned using Perkin Elmer Frontier FT-IR instrument operated by CPU32M software. The sample buffer was prepared by adding 
$100 \mathrm{mM}$ sodium chloride $(\mathrm{NaCl})$ into deuterium oxide $\left(\mathrm{D}_{2} \mathrm{O}\right)$ (van de Weert et al., 2001). The dried and control samples were diluted to $5 \mathrm{mg} / \mathrm{ml} \beta-\mathrm{Lg}$ concentration using the buffer. The SDD samples used in these tests were collected after $600 \mathrm{~s}$ of drying at $65{ }^{\circ} \mathrm{C}$ and $80{ }^{\circ} \mathrm{C}$. A total of 16 scans at $4 \mathrm{~cm}^{-1}$ resolution were acquired at $0.2 \mathrm{~cm} / \mathrm{s}$ scanning rate within $650 \mathrm{~cm}^{-1}$ to $4000 \mathrm{~cm}^{-1}$ IR region. In order to identify the peak positions, the baseline was subtracted from the acquired spectra to avoid the effect of the buffer. It was followed by a 13-point second derivative analysis to the amide region-I $\left(1600-1700 \mathrm{~cm}^{-1}\right)$ by Perkin Elmer's proprietary software (Version 10.03.06).

\subsubsection{Modelling of Drying Kinetics using the Reaction Engineering Approach (REA)}

Generally, the drying rate of a material can be expressed by equation (2).

$$
m_{s} \frac{d X}{d t}=-h_{m} A\left(\rho_{v, s}-\rho_{v, b}\right)
$$

where $m_{s}$ is the dry solid mass of the sample $(\mathrm{kg}), X$ is the average moisture content on dry basis $\left(\mathrm{kg} \cdot \mathrm{kg}^{-1}\right), t$ is the time $(\mathrm{s}), \rho_{v, s}$ is the water vapor concentration at interface $\left(\mathrm{kg} \cdot \mathrm{m}^{-3}\right), \rho_{v, b}$ is the water vapor concentration in the drying medium $\left(\mathrm{kg} . \mathrm{m}^{-3}\right), h_{m}$ is the mass transfer coefficient $\left(\mathrm{m} . \mathrm{s}^{-1}\right)$ and $A$ is the surface area of the droplet/particle $\left(\mathrm{m}^{2}\right)$.

The surface vapor concentration $\left(\rho_{v, s}\right)$ can then be expressed in terms of saturated vapour concentration $\left(\rho_{v, s a t)}\right.$ as:

$\rho_{v, s}=\exp \left(\frac{-\Delta E_{v}}{R T}\right) \rho_{v, s a t}(T)$

where, $\Delta E_{v}(\mathrm{~J} / \mathrm{mol})$ represents the additional difficulty to remove moisture from the material when the relative humidity at the surface is less than one. The $\Delta E_{v}$ is moisture content $(X)$ dependent, $R$ is the universal gas constant $\left(\mathrm{J} \cdot \mathrm{mol}^{-1} \cdot \mathrm{K}^{-1}\right)$ and $T$ is the temperature of the 
172 droplet/particle being dried $(\mathrm{K}) . \rho_{v, \text { sat }}\left(\mathrm{kg} \cdot \mathrm{m}^{-3}\right)$ is the saturated water vapor concentration which 173 can be estimated as a function of temperature as given by equation (4) (Lin \& Chen, 2006, 174 2007).

$\rho_{v, s a t}=4.844 \times 10^{-9}(T-273)^{4}-1.4807 \times 10^{-7}(T-273)^{3}+2.6572 \times 10^{-5}(T-273)^{2}$ $-4.8613 \times 10^{-5}(T-273)+8.342 \times 10^{-3}$

176 The mass balance (equation 2) can be rearranged into equation (5).

177

$$
m_{s} \frac{d X}{d t}=-h_{m} A\left[\exp \left(\frac{-\Delta E_{v}}{R T}\right) \rho_{v, s a t}(T)-\rho_{v, b}\right]
$$

178 From equation (5), it can be observed that the REA is expressed as ordinary differential 179 equation with respect to time. It must be noted that the REA does not predict the moisture 180 distribution within the droplet/particle rather it predicts the average moisture content as a 181 function of time.

182 The activation energy $\left(\Delta E_{v}\right)$ can be calculated by rearranging equation (5) into equation (6).

$$
\Delta E_{v}=-R T \ln \left[\frac{-m_{s} \frac{d X}{d t} \frac{1}{h_{m} A}+\rho_{v, b}}{\rho_{v, s a t}(T)}\right]
$$

184 The rate of moisture loss $(d X / d t)$ is experimentally determined. The dependence of activation energy on average moisture content can be calculated using equation (7).

$186 \frac{\Delta E_{v}}{\Delta E_{v, b}}=f\left(X-X_{b}\right)$

187 Where, $f$ is a function of the difference in water content $\left(X-X_{b}\right), X_{b}$ is the equilibrium moisture content under the condition of the drying air $\left(\mathrm{kg}^{\mathrm{kg}} \mathrm{kg}^{-1}\right), \Delta E_{v, b}$ is the 'equilibrium' activation 
energy representing the maximum $\Delta E_{v}$ determined by the relative humidity and temperature of the drying, as given by equation (8).

$$
\Delta E_{v, b}=-R T_{b} \ln \left(R H_{b}\right)
$$

$R H_{b}$ is the relative humidity of drying air and $T_{b}$ is the drying air temperature (K).

In order to predict the temperature profile of the drying droplet, the mass balance equation represented by equation (5) is coupled with the heat balance. For the single droplet drying system mentioned above, the heat balance can be represented by equation (9).

$$
m C_{p d} \frac{d T}{d t}=h A\left(T_{b}-T\right)+m_{s} \frac{d X}{d t} \Delta H_{v}+0.5 \pi d_{f} \sqrt{h d_{f} k_{f}}\left(T_{b}-T\right)
$$

where $m$ is the mass of the droplet/particle $(\mathrm{kg}), C_{p d}$ is the specific heat capacity of droplet/particle $\left(\mathrm{J} \cdot \mathrm{kg}^{-1} \cdot \mathrm{K}^{-1}\right), h$ is the heat transfer coefficient $\left(\mathrm{W} \cdot \mathrm{m}^{-2} \cdot \mathrm{K}^{-1}\right)$ and $\Delta H_{v}$ is the latent heat of vaporization of water $\left(\mathrm{J}^{\mathrm{kg}} \mathrm{kg}^{-1}\right)$. Similarly, $d_{f}$ and $k_{f}$ is the diameter (m) and thermal conductivity W/(m.k) of the glass filament, respectively. The third term in the right-hand side of equation (9) represents the heat conduction through the filament to the droplet. In single droplet drying experiments, the drops were suspended on the tip of a glass filament. Hence, the amount of thermal energy conducted to the droplet through the glass filament should be included in the energy balance equation. The heat conducted through the filament can be quantified and compensated assuming the filament as an infinite fin (Adhikari et al., 2007).

using the established Ranz-Marshall correlations for Sherwood number $\left(S_{h}\right)$ and Nusselt number $\left(N_{u}\right)$ of spherical droplets subjected to convective air drying (Ranz \& Marshall, 1952). In terms of $S_{h}$ and $N_{u}$ both the $h_{m}$ and $h$ can be expressed as given by equations (10) and (11), respectively. 
$211 S_{h}=\frac{h_{m} d}{D_{v}}=2+0.6 R_{e}^{0.5} S_{c}^{0.33}$

$212 \quad N u=\frac{h d}{k_{b}}=2+0.6 R_{e}^{0.5} P_{r}^{0.33}$

213 where, $d$ is the diameter of the evaporating droplet/particle, $D_{v}$ is the diffusivity of water vapour $214\left(\mathrm{~m}^{2} / \mathrm{s}\right)$ and $k_{b}$ is the thermal conductivity of air $\left(\mathrm{W} \cdot \mathrm{m}^{-1} \cdot \mathrm{K}^{-1}\right) . R_{e}, S_{c}, P_{r}$ are dimensionless

215 Reynolds, Schmidt and Prandtl numbers, respectively which were calculated based on the 216 drying air conditions.

The drying conditions of the single droplet drying of the $\beta$ - $\mathrm{Lg}$ droplets are listed in Table 1. The air velocity and the temperature of the drying air were controlled by using precision rotameter (Influx AI29, Influx Measurements Ltd, United Kingdom) and a PID controller (C91 Brain Child electronics, OneTemp Pty Ltd. Australia), respectively. The relative humidity values of the drying air were measured by using EL-USB relative humidity data logger (Lascar Electronics, UK) and were found to be $2 \pm 0.5 \%$ at the two sets of drying temperatures. The initial moisture content of droplet was determined based on the mass of the droplet and the solid concentration of the solution while the diameter of the droplet was calculated based on the mass of the droplet and density of the solution and assuming the droplet to be spherical. The physio-chemical properties of $\beta$-Lg solution used in the drying kinetics modelling are determined as described in the section below.

\subsubsection{Physicochemical properties of $\beta$-Lg solution used in the drying kinetics modelling} given by equation (12). 

activity (dimensionless) and $c$ and $k$ are GAB constants. and the GAB equation was fitted to these adsorption isotherm data. Method of determination of adsorption isotherms is described in the following section (Section 2.2.6). The GAB model followed the measured adsorption isotherms reasonably well with average absolute error of $4.5 \pm 0.5 \%$ (Fig. 1). This fitting yielded $\mathrm{m}_{\mathrm{o}}$, c, and $\mathrm{k}$ values of $3.37,2.64$ and 0.96 , respectively. The data points show that the sorption isotherms at $20{ }^{\circ} \mathrm{C}$ and $37{ }^{\circ} \mathrm{C}$ are very close to each other. This observation indicates that the effect of temperature on the adsorption isotherm is insignificant compared to the effect of the moisture content in this temperature range (Adhikari et al., 2005). Hence, only the moisture dependence of water activity was considered in the modeling exercise. For REA modelling the equilibrium moisture contents $\left(X_{e}\right)$ of $\beta$-Lg were estimated to $0.03 \mathrm{~kg}$ water $/ \mathrm{kg}$ dry solids. Okos, 1986). 
where $C p$ is the sample specific heat $(\mathrm{J} / \mathrm{kg} \mathrm{K})$

254

255

256

\subsubsection{Adsorption Isotherm measurement}

The moisture adsorption isotherms for $\beta$-Lg powders were measured using the static 257 gravimetric method (Stitt, 1958; Bronlund \& Paterson, 2004). Nine saturated salt solutions

258

259

260

261

262

263

264

265

266

267

268

269

270

271

272

273

274 (Meerdink, G, Van'tRiet, 1995; Haque et al., 2013b).

275 model.

\subsubsection{Modelling of Denaturation Kinetics} were prepared in air tight desiccators with the salts lithium chloride, potassium acetate, magnesium chloride, potassium carbonate, magnesium nitrate, copper chloride,sodium chloride, potassium chloride and potassium sulfate for the corresponding water activities ranging from 0.1 to 0.9 . Approximately $5 \mathrm{gm}$ of $\beta$ - $\mathrm{Lg}$ sample from each type were taken in clean and dry pre-weighed petri dishes. The petri dishes were then transferred into the desiccators and incubated at $20{ }^{\circ} \mathrm{C}$ and $37{ }^{\circ} \mathrm{C}$. All the samples, in both experimental sets, were allowed to equilibrium over a period of 20 days; until before appearance of any microbe on the samples. The samples were weighed periodically at every alternative day from $14^{\text {th }}$ day of incubation to find equilibrium state of weight. The moisture contents of the samples were determined using oven drying method at $105^{\circ} \mathrm{C}$. Three replications were kept for each sample and the average values were taken as equilibrium moisture contents (EMC) to fit the GAB

The denaturation kinetics of enzymes and proteins during convective drying can generally be expressed by the first-order reaction kinetics model as expressed by equation (15)

$\frac{d C}{d t}=-k_{d} C$

where, $k_{d}$ is the denaturation rate constant $\left(\mathrm{s}^{-1}\right), C$ is the protein concentration (\%) at each time. 
277 The denaturation rate constant, $k_{d}$ can be expressed as a function of temperature and water 278 content of the drying droplet as given by equation (16).

$279 \quad k_{d}=k_{o} \exp \left(a X-\frac{E_{a}+b X}{R T}\right)$

280 where, $T$ is the droplet temperature $(\mathrm{K}), X$ is the moisture content of the droplet $\left(\mathrm{kg} \cdot \mathrm{kg}^{-1}\right), R$ is 281 the universal gas constant and $E_{a}$, is the apparent activation energy $\left(\mathrm{J} \cdot \mathrm{mol}^{-1}\right), k_{o}\left(\mathrm{~s}^{-1}\right), a$ and $b$ 282 are the model constants.

The parameters $a, b, k$ and $E_{a}$ were estimated considering the simultaneous effects of 284 water concentration $(X)$ and temperature $(T)$ of the drying droplet. A least square algorithm (Microsoft Solver ${ }^{\mathrm{TM}}$, Microsoft Inc., Washington, USA) was used in determining the values of 286 these constants for $\beta$-Lg denaturation kinetics data. $X$ and $T$ used in equation (16) are based on 287 the REA-predictions. 


\section{Results and Discussion}

290

291

292

293

294

296

297

299

300

301

302

303

304

305

306

307

308

309

310

311

312

\subsection{Denaturation of $\beta-\mathrm{Lg}$ during Convective Drying}

It can be seen from the elution profile of $\beta$-Lg in reversed-phase HPLC (Fig. 2) that the elution times of $\beta-\operatorname{Lg} B$ and $\beta-\operatorname{Lg} A$ are 22.50 , and $23.20 \mathrm{~min}$, respectively. This order of elution of these proteins in RP-HPLC is in good agreement with their respective elution time reported in the literature (Parris, N., Baginski, 1991; Haque et al., 2013a). The data presented in this manuscript represent the mean values of the two peaks of $\beta-\operatorname{LgA}$ and $\beta-\operatorname{LgB}$.

As can be seen from the Fig.3, various drying temperatures caused different degrees of denaturation of $\beta-\mathrm{Lg}$. When dried at $65^{\circ} \mathrm{C}$ for 10 minutes, nearly $24.4 \% \beta-\mathrm{Lg}$ was found to be denatured. Higher temperature $\left(80^{\circ} \mathrm{C}\right)$ caused higher degree $(30.85 \%)$ of denaturation for the same period of drying. The native state of $\beta-\mathrm{Lg}$ was found to decrease significantly when it reached a state of irreversible denaturation (for example at $240 \mathrm{~s} ; 80^{\circ} \mathrm{C}$ ). Before $\beta$ - $\mathrm{Lg}$ reached its state of irreversible denaturation, reversible denaturation occurred. The free cysteine residues present in the $\beta-\mathrm{Lg}$ structure were found to be excited at the state of reversible denaturation. Due to prolonged drying stresses, the peptides of $\beta$-Lg were exposed to such an extent that they started to aggregate. However, extent of denaturation of $\beta$ - $\mathrm{Lg}$ in the current study, where the protein was dried individually, is much lower (about $31 \%$ ) than our previous study (about 70\%) during drying of WPI (as a whole) where numerous proteins were present together with $\beta$-Lg as mixture (Haque et al., 2013a). The principal reason might be the proteinprotein interactions. In aqueous state one group of proteins interact with different proteins as they interact with ions, and other non-protein materials such as lipids, nucleic acids, and carbohydrates (Waugh, 1954). These interactions may range from covalent bonds and electrostatic exchanges to the weaker electronic van der Waals' attractive forces. In a condition likewise the current study where the protein molecule is subjected to a structural change, the 
bonding groups of polypeptides bring into positions which allow them to reversible or irreversible structural changes. Such condition can lead to remarkable chemical or physical changes of proteins (Waugh, 1954).

\subsection{Effect of drying on the conformation of $\beta-\mathrm{Lg}$}

Amide I region of the infrared spectra was chosen to study the change in the conformational $\beta$ - $\mathrm{Lg}$ during drying. The vibrations in these cases originated mainly from $\mathrm{C}=\mathrm{O}$ stretching of peptide bonds. These vibrations produced absorption peaks at different location of the IR spectra. However, the original peaks were very intrinsic and could not be separated (Fig. 4A). Therefore, the second derivative mathematical tool was used to locate the secondary structural features (such as $\alpha$-helix, $\beta$-sheet and turn).

Denaturation of protein due to external stress can be identified by observing the shifted, newly appeared and disappeared peaks within the studied region of IR spectra. The peaks from $1620 \mathrm{~cm}^{-1}$ to $1640 \mathrm{~cm}^{-1}$, and $1674 \mathrm{~cm}^{-1}$ to $1680 \mathrm{~cm}^{-1}$ are assigned to the $\beta$-sheet secondary structure (Fig. 4B). Similarly, the peaks from $1641-1647 \mathrm{~cm}^{-1}$ are assigned to random coil. The peaks appearing in $1648-1660 \mathrm{~cm}^{-1}$ are assigned to $\alpha$-helix, and those appearing in the vicinity of $1663,1671,1683,1694 \mathrm{~cm}^{-1}$ are assigned to $\beta$-turn (Haque et al., 2015b; Ngarize et al., 2004). It was found that the drying stresses had increased the intensity but narrowed the peaks near $1650 \mathrm{~cm}^{-1}$ and $1682 \mathrm{~cm}^{-1}$, and two other peaks appeared at the vicinity of $1618 \mathrm{~cm}^{-1}$ and $1662 \mathrm{~cm}^{-1}$. These changes are indicate that the proportion of random coil and $\beta$-sheet increased due to uncoiling of $\alpha$-helix, and transformation of $\beta$-turn into $\beta$-sheet. This type of change in secondary structure is common in many proteins and is attributed to the formation of intermolecular hydrogen-bonded anti-parallel $\beta$-sheet structures which leads to aggregation or denaturation (Clark et al., 1981).

\subsection{Prediction of Drying Kinetics by REA}



is the fingerprint of the REA, is firstly determined as a function of the moisture content difference $\left(X-X_{b}\right)$. Based on the experimental data of moisture content, temperature, and surface area of droplet/particle during drying, the activation energy was calculated from the convective drying run at $80{ }^{\circ} \mathrm{C}$ using equation (6). The activation energy was then divided by the equilibrium activation energy (equation 8 ) to yield the relative activation energy as shown in equation (7). The relative activation energy was then correlated with the moisture content difference $\left(X-X_{b}\right)$. The relative activation energy of $\beta-\operatorname{Lg}$ was found to be represented well by equation (17) given below.

$\frac{\Delta E_{v}}{\Delta E_{v, b}}=1+826453.696\left(X-X_{b}\right)^{1.806} \exp \left[-13.666\left(X-X_{b}\right)^{0.181}\right]$

As can be seen from Fig.5, equation (17) provides a good fit to the experimental relative activation energy data with $\pm 5.7 \%$ errors $\left(R^{2}=0.946 \pm 0.03\right)$. The relative activation energy was zero at the beginning of drying and keeps increasing during drying. When equilibrium moisture content was attained, the relative activation energy was one as shown Fig. 5. The relative activation energy is essentially material characteristics which represent the difficulty to remove moisture from the materials being dried.

In order to predict the moisture content and temperature profiles during drying, the mass and heat balance equations represented by equations (5) and (9), respectively were simultaneously solved. The equilibrium and relative activation energy, shown in equations (8) and (17), respectively were used for this purpose. The results obtained from the model 357 predictions were then compared with the experimental moisture and droplet temperature 358 history data (shown in Fig. 6 and 7). The results of modelling indicate that the REA-based model accurately describes both moisture content and temperature during drying. The average 
errors between the experimental and predicted data for moisture-time and the temperature-time profiles were $\pm 5.80 \%\left(R^{2}=0.935\right)$ and $\pm 3.51 \%\left(R^{2}=0.991\right)$, respectively at drying temperature of $65{ }^{\circ} \mathrm{C}$. Similarly, the average errors between the experimental and predicted moisture content-time and temperature-time profiles were $\pm 5.50 \%\left(R^{2}=0.946\right)$ and $\pm 3.40 \%\left(R^{2}=\right.$ 0.956), respectively at $80{ }^{\circ} \mathrm{C}$. These results indicate that the REA based temperature and moisture kinetics models can be confidently applied in predicting the moisture and temperature histories of $\beta-\mathrm{Lg}$ droplets in convective drying environment.

\subsection{Prediction of Denaturation Kinetics}

The experimental and predicted denaturation kinetics of $\beta$ - Lg at both temperatures $\left(65^{\circ} \mathrm{C}\right.$ and $\left.80^{\circ} \mathrm{C}\right)$ are shown in Figs. 6 and 7, respectively. These figures illustrate the effects of dehydration and droplet temperature on the denaturation kinetics. The predicted denaturation kinetics data was generated by using first order reaction kinetics (equations (15) and (16)) in which the REA-predicted moisture content and temperature are incorporated in the model. The model constants are evaluated based on least square method as presented in Table 2 . As can be seen from Figs. 6 and 7, the predicted denaturation kinetics data points follow the experimental denaturation kinetics data reasonably well (with $\pm 6.0 \%$ errors). The coefficients of determination $\left(R^{2}\right)$ values of these predictions were 0.96 and 0.94 at $65{ }^{\circ} \mathrm{C}$ and $80{ }^{\circ} \mathrm{C}$, respectively. The prediction was less accurate in the early stage of drying as reversible denaturation occurred up to 250s (Fig. 3). This reversible denaturation produced fluctuation of hydrophobicity while measuring the denaturation kinetics using RP-HPLC. The activation

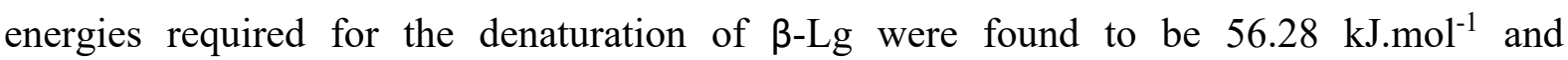
$54.72 \mathrm{~kJ} . \mathrm{mol}^{-1}$ during drying at $65^{\circ} \mathrm{C}$ and $80^{\circ} \mathrm{C}$, respectively. The statistical analysis suggests that the values were not significantly different $(\mathrm{p}>0.05)$. The value of the denaturation energy is also comparable with that of inactivation energy of whey protein isolate (WPI) (Haque et al., 2013b). 


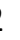

\subsection{Droplet Morphology of $\beta-\mathrm{Lg}$}

The images of $\beta$ - $\mathrm{Lg}$ droplets captured at the beginning and at the end of drying (600 s) are presented in Fig. 8. $\beta$-Lg droplet was found to produce buckled particle after drying at both temperatures. Although the $\beta$-Lg droplet was not strong enough to resist the deformation of its shape during drying, it had formed firm glassy skin toward the end of the drying.

\section{Conclusions}

The drying and denaturation kinetics of $\beta$ - $\mathrm{Lg}$ were measured during convective air drying at $65^{\circ} \mathrm{C}$ and $80{ }^{\circ} \mathrm{C}$. Both the drying kinetics and denaturation kinetics were predicted using REA-based models, and first order reaction kinetics, respectively. At the end of drying at $65{ }^{\circ} \mathrm{C}$ and $80{ }^{\circ} \mathrm{C}$, the denaturation of $\beta-\operatorname{Lg}$ was $24.40 \%$ and $30.85 \%$, respectively. The REA-based model predicted moisture and temperature histories of the $\beta$-Lg droplets within $5.80 \%$ and $3.52 \%$ average absolute errors, respectively. Coupling the REA-based model with the first order denaturation kinetics was able to predict the denaturation kinetics of $\beta$-Lg both at 65 and $80^{\circ} \mathrm{C}$, within $6.20 \%$ error. The information generated in this study can be used to tailor the convective drying parameters (especially spray drying ones) to produce minimally denatured $\beta$-Lg powders. 
405

406

407

408

409

410

411

412

413

414

415

416

417

418

419

420

421

422

423

424

Adhikari, B., Howes, T., Bhandari, B. R., 2007. Use of solute fixed coordinate system and method of lines for prediction of drying kinetics and surface stickiness of single droplet during convective drying. Chemical Engineering and Processing, 46, 405-419.

Adhikari, B., Howes, T., Lecomte, D., Bhandari, B. R., 2005. A glass transition temperature approach for the prediction of the surface stickiness of a drying droplet during spray drying. Powder Technology, 149, 168-179.

Anandharamakrishnan, C., Rielly, C.D., Stapley, A.G.F., 2007. Effects of process variables on the denaturation of whey proteins during spray drying. Drying Technology, 25(5), 799-807.

Bronlund, J., Paterson, T., 2004. Moisture sorption isotherms for crystalline, amorphous and predominantly crystalline lactose powders. International Dairy Journal, 14, 247-254.

Chatterton, D.E.W., Smithers, G., Roupas, P., Brodkorb, A., 2006. Bioactivity of $\beta$ lactoglobulin and $\alpha$-lactalbumin-Technologicalimplications for processing: A Review. International Dairy Journal, 16, 1229-40.

Chavez, B.E., Ledeboer, A.M., 2007. Drying of probiotics: optimization of formulation and process to enhance storage survival. Drying Technology, 25 (7-8), 1193-1201.

Che, L., Li, D., Chen. X.D., 2012. Convective drying kinetics of single droplets of aqueous glucose. Drying Technology, 30, 1029-1036.

Choi, Y., Okos, M.R., 1986. Effects of temperature and composition on the thermal properties of foods. In Food Engineering and Process Applications. Vol. 1, Transport Phenomenon, L. Maguer, P. Jelen (eds), Elsevier; New York, 93-101. 
425 Clark, A. H., Saunderson, D.H.P., Suggett, A., 1981. Infrared and laser-Raman spectroscopic 426 studies of thermally-induced globular protein gels. International journal of peptide and protein 427 research. 17, 353-64.

428 Ferreira, I.M.P.L.V.O., Caçote, H., 2003. Detection and quantification of bovine, ovine and caprine milk percentages in protected denomination of origin cheeses by reversed-phase highperformance liquid chromatography of beta-lactoglobulins. Journal of Chromatography. A, $1015,111-118$.

Haque, M. A. Aldred, P., Chen, J., Adhikari, B., 2015a. Drying and denaturation characteristics of whey protein isolate in the presence of lactose and trehalose. Food Chemistry, 177, 8-16.

434 Haque, M. A., Putranto, A., Adhikari, B., 2016. Predictions of Drying Kinetics of Aqueous Engineering Approach (REA). Journal of Food Engineering, 189, 29-36.

Haque, M.A., Aldred. P., Chen, J., Barrow, C.J., Adhikari, B., 2013a. Comparative study of denaturation of whey protein isolate (WPI) in convective air drying and isothermal heat treatment processes. Food Chemistry, 141, 702-711.

441 kinetics of whey protein isolate (WPI) during convective air drying process. Drying 442 Technology, 31 (13-14), 1532-1544.

443 Haque, M.A., Adhikari, B., 2014. Drying and denaturation of proteins in spray drying process. 444 In A. S. Mujumdar (Ed.), Handbook of industrial drying, $4^{\text {th }}$ Ed. CRC Press, Taylor and 445 Francis group, NW, USA, pp 971-984. 
446 Haque, M.A., Chen, J., Aldred, P., Adhikari, B., 2015b. Denaturation and Physical 447 Characteristics of Spray Dried Whey Protein Isolate Powders Produced in the Presence and Absence of Lactose, Trehalose and Polysorbate 80. Drying Technology, 33, 1243-54. to $\beta$-Lactoglobulin by Preparing an Edible Conjugate with Cationic Saccharide Using Microbial Mransglutaminase (MTGase). Bioscience, Biotechnology and Biochemistry, 72(5), $1227-34$.

453 Jime'nez-Castano, L., Villamiel, M., Martı'n-Alvarez, P.J.,

454 Olano, A., Lo'pez-Fandiño, R., 2005. Effect of the dry-heating conditions on the 455 glycosylation of $\beta$-lactoglobulin with dextran through the Maillard reaction. Food 456 Hydrocolloids, 19, 831-37.

Lin, S. X. Q., Chen, X. D., 2007. The reaction engineering approach to modelling the cream and whey protein concentrate droplet drying. Chemical Engineering and Processing, 46, 437443.

Lin, S.X.Q., Chen, X. D., 2006. A Model for Drying of an Aqueous Lactose Droplet Using the Reaction Engineering Approach. Drying Technology, 24, 1329-1334.

Meerdink, G, Van'tRiet, K., 1995. Prediction of product quality during spray drying. Transactions of the IChemE Part C: Food and Bioproduct Processing, 73, 165-170.

Ngarize, S., Herman, H., Adams, A., Howell, N., 2004. Comparison of changes in the secondary structure of unheated, heated, and high-pressure-treated $\beta$-lactoglobulin and ovalbumin proteins using Fourier transform Raman spectroscopy and self-deconvolution. Journal of Agricultural and Food Chemistry, 52, 6470-6477. 
468 Parris, N., Baginski, M. A., 1991. A rapid method for the determination of whey protein denaturation. Journal of Dairy Science, 74, 58-64.

470 Patel, K. C., Chen, X. D., 2005. Prediction of spray-dried product quality using two simple 471 drying kinetics models. Journal of Food Process Engineering, 28, 567-594.

472 Ranz, W. E., Marshall, W. R., 1952. Evaporation from drops. Chemical Engineering and 473 process, $48(3), 141-146$.

474 Sano, Y., Keey, R.B., 1982. The drying of a spherical particle containing colloidal material 475 into a hollow sphere. Chemical Engineering Science, 37(6), 881-889.

476 Shpigelman, A., Israeli, G., Livney, Y.D., 2010. Thermally-induced protein polyphenol co477 assemblies: beta lactoglobulin-based nanocomplexes as protective nanovehicles for EGCG. 478 Food Hydrocolloids, 24, 735-43

479 Stitt, F., 1958. Moisture equilibrium and the determination of water content in dehydrated 480 foods. In Society of Chemical Industry. Fundamental aspects of the dehydration of foodstuffs, 481 Metchim and Son, London. pp. 67-87. van de Weert, M., Haris, P.I., Hennink, W. E., Crommelin, D.J.A., 2001. Fourier Transform Infrared Spectrometric Analysis of Protein Conformation: Effect of Sampling Method and Stress Factors. Analytical Biochemistry, 297,160-169. 9, 325-437. 


\section{LIST OF FIGURES AND TABLES}

\section{Figures}

Fig. 1. Changing of adsorption isotherm of $\beta-\mathrm{Lg}$ powder at $20^{\circ} \mathrm{C}$ and $37^{\circ} \mathrm{C}$.

Fig. 2. Reversed-phase HPLC chromatograms for $\beta-\operatorname{Lg}$ (fraction $A$ and $B$ ). The two runs with the same solution have confirmed the good accuracy of the instrument.

Fig. 3. Denaturation profile during convective air drying of aqueous $\beta$ - $\operatorname{Lg}$ droplet at $65^{\circ} \mathrm{C}$ and $80{ }^{\circ} \mathrm{C}$.

Fig. 4. (A) Absorbance and (B) second derivative spectra of amide I region of the native and single droplet dried $\beta-\mathrm{Lg}$ (black line, blue line \& red line indicates native, $65^{\circ} \mathrm{C}$ and $80{ }^{\circ} \mathrm{C}$ treated spectra, respectively).

Fig. 5. Relative activation energy curves for drying of $\beta$-Lg droplets at $65{ }^{\circ} \mathrm{C}$ and $80{ }^{\circ} \mathrm{C}$ drying temperature.

Fig. 6. Experimental and predicted moisture content (MC) and denaturation profiles of $\beta-\mathrm{Lg}$ during droplet drying at $65^{\circ} \mathrm{C}$ and $80{ }^{\circ} \mathrm{C}$ drying temperature.

Fig. 7. Experimental and predicted droplet temperature $(\mathrm{T})$ and denaturation profiles of $\beta-\mathrm{Lg}$ during droplet drying at $65^{\circ} \mathrm{C}$ and $80{ }^{\circ} \mathrm{C}$.

Fig. 8. Morphology of $\beta$-Lg droplet captured (A) before drying and after drying at (B) $65^{\circ} \mathrm{C}$ and (C) $80^{\circ} \mathrm{C}$.

\section{Tables}

Table 1. The drying conditions during single droplet drying of $\beta-\mathrm{Lg}$

Table 2. Kinetic parameters in prediction of denaturation of $\beta-\mathrm{Lg}$ during droplet drying 
FIGURES

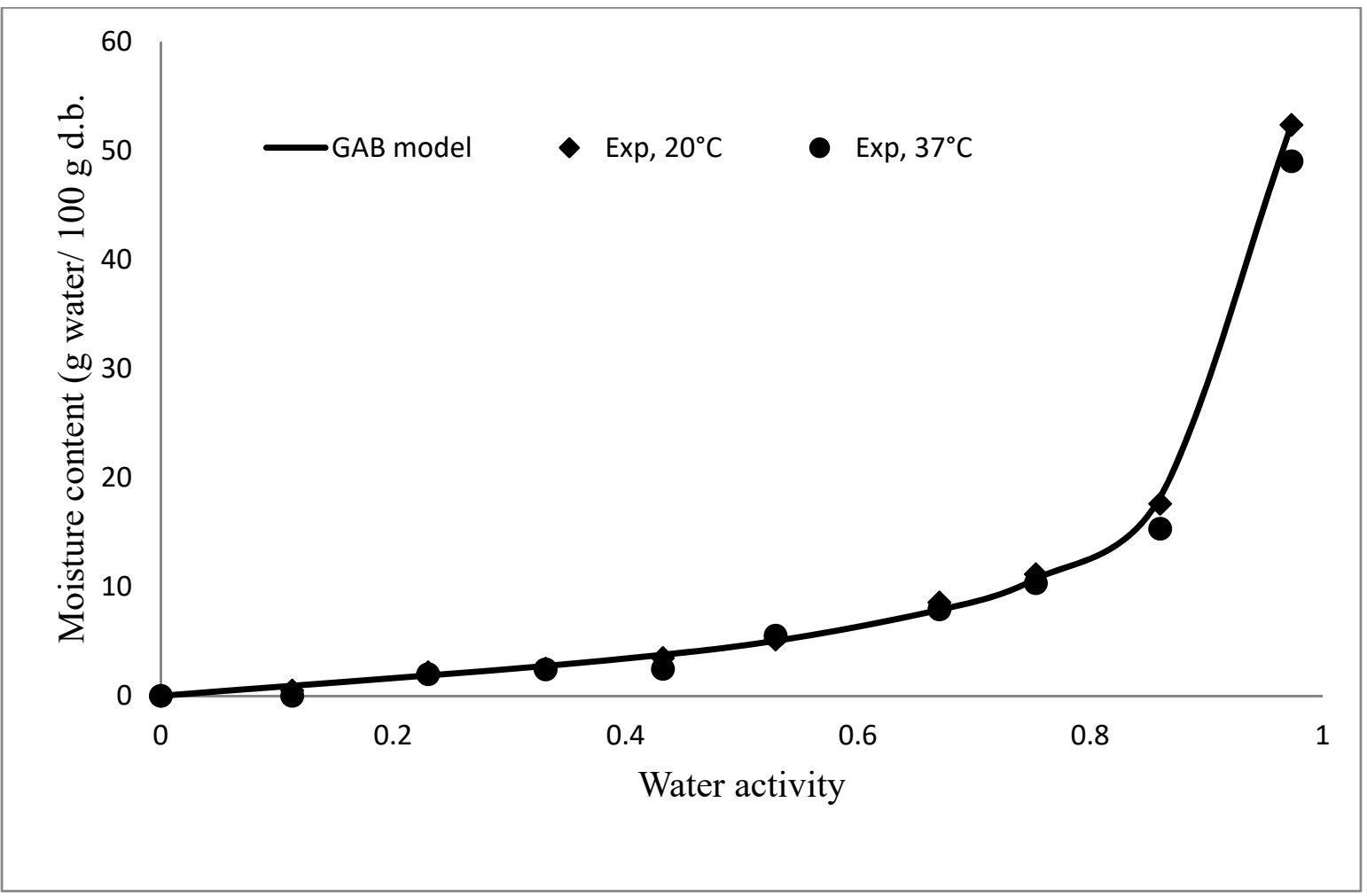

518

519 Fig. 1. Changing of adsorption isotherm of $\beta-\operatorname{Lg}$ powder at $20^{\circ} \mathrm{C}$ and $37^{\circ} \mathrm{C}$. 


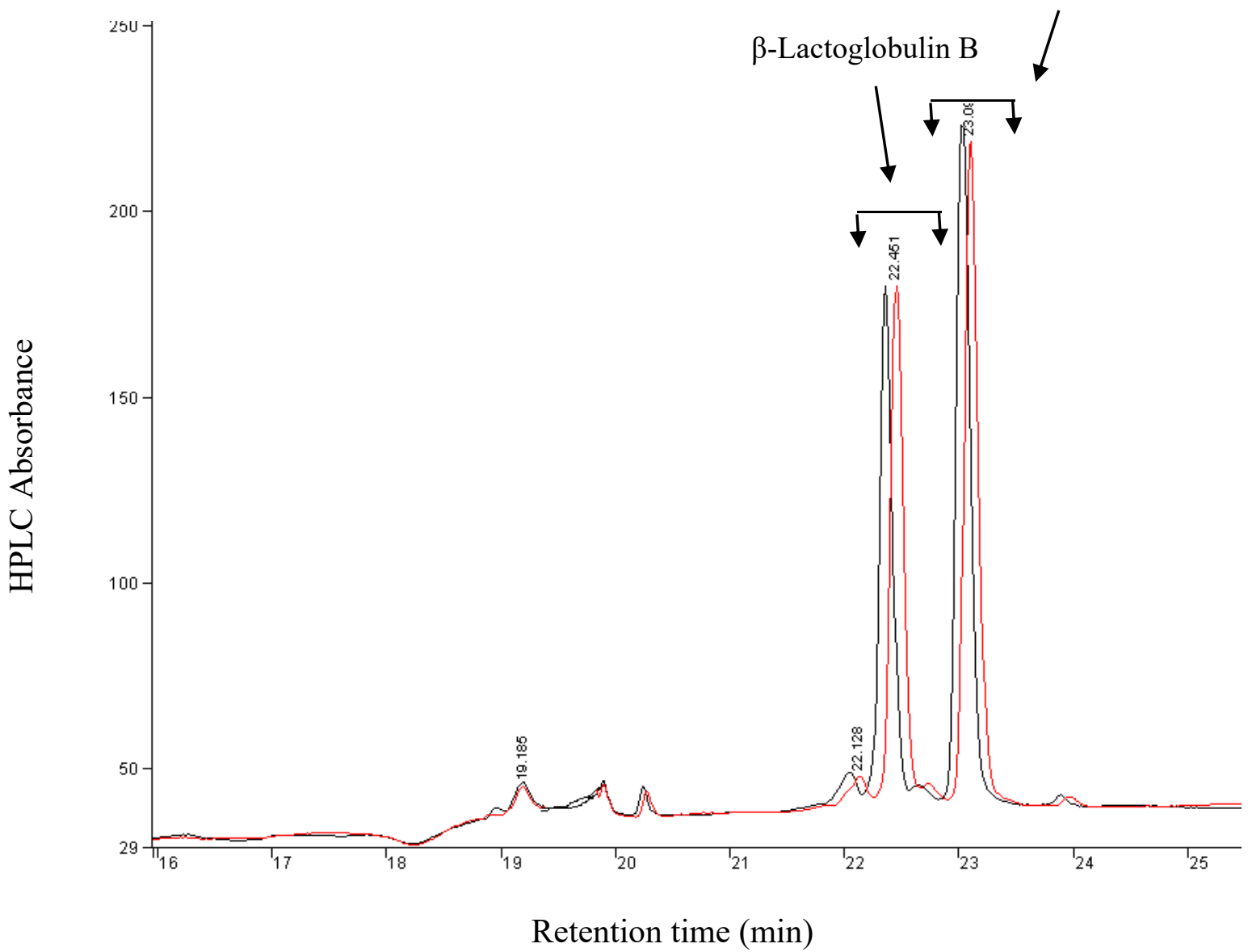

523

524 Fig. 2. Reversed-phase HPLC chromatograms for $\beta$ - $\operatorname{Lg}$ (fraction A and B). The two runs with the same solution have confirmed the good accuracy of the instrument. 


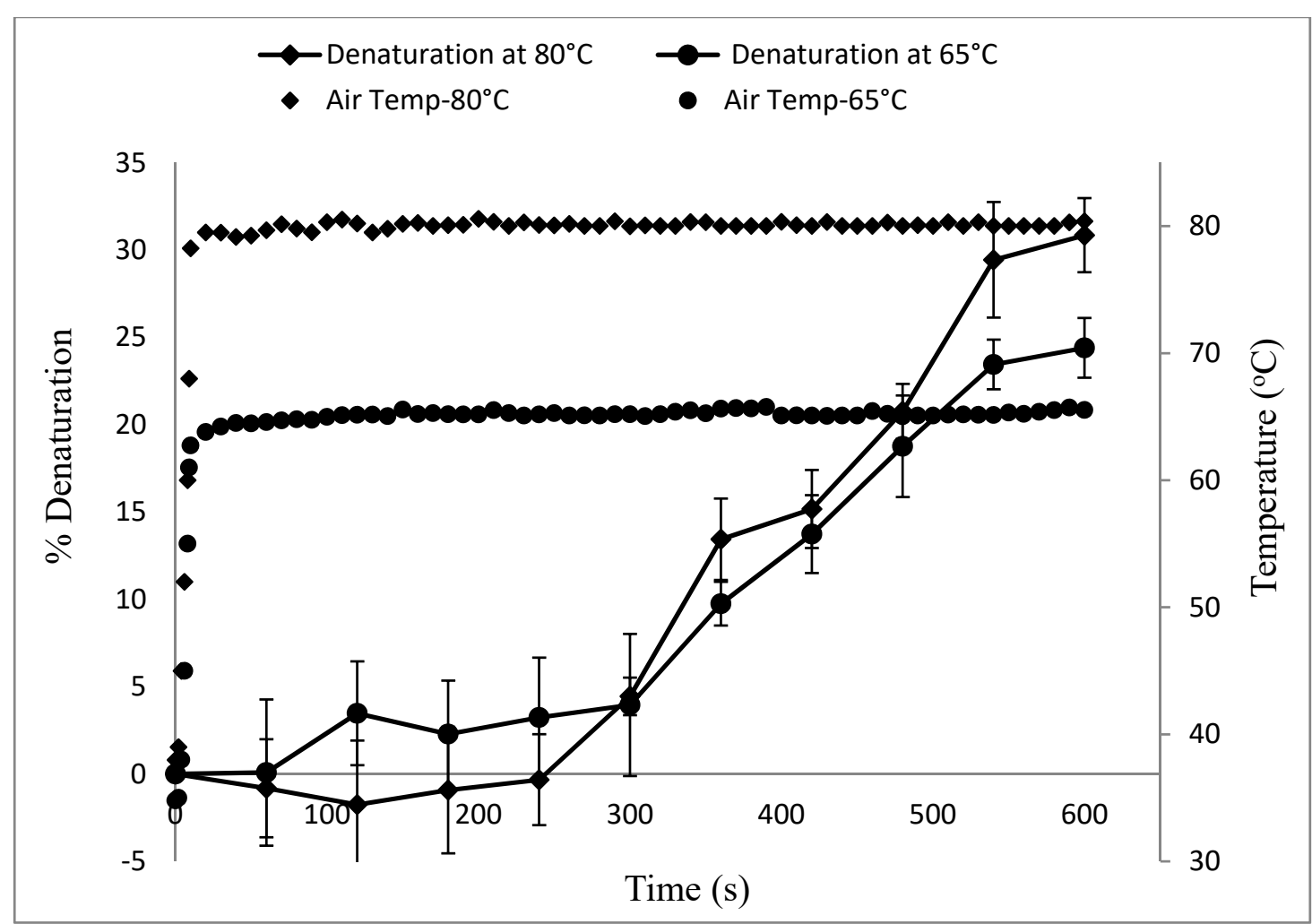

530 Fig. 3. Denaturation profile during convective air drying of aqueous $\beta$-Lg droplet at $65{ }^{\circ} \mathrm{C}$ and $80{ }^{\circ} \mathrm{C}$. 


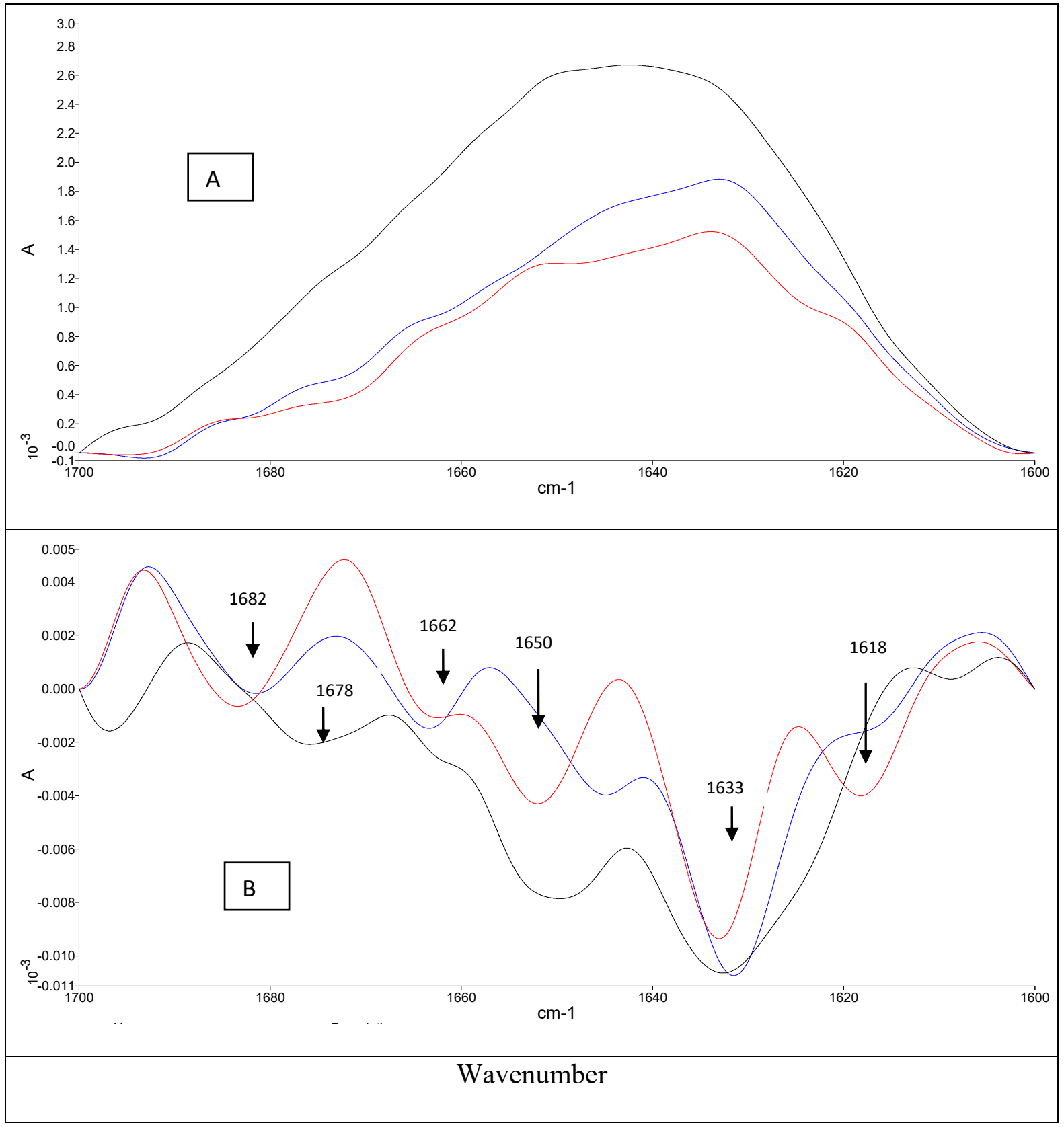

534

535 Fig. 4. (A) Absorbance and (B) second derivative spectra of amide I region of the native and 536 single droplet dried $\beta-\mathrm{Lg}$ (black line, blue line \& red line indicates native, $65{ }^{\circ} \mathrm{C}$ and $80{ }^{\circ} \mathrm{C}$ treated spectra, respectively). 


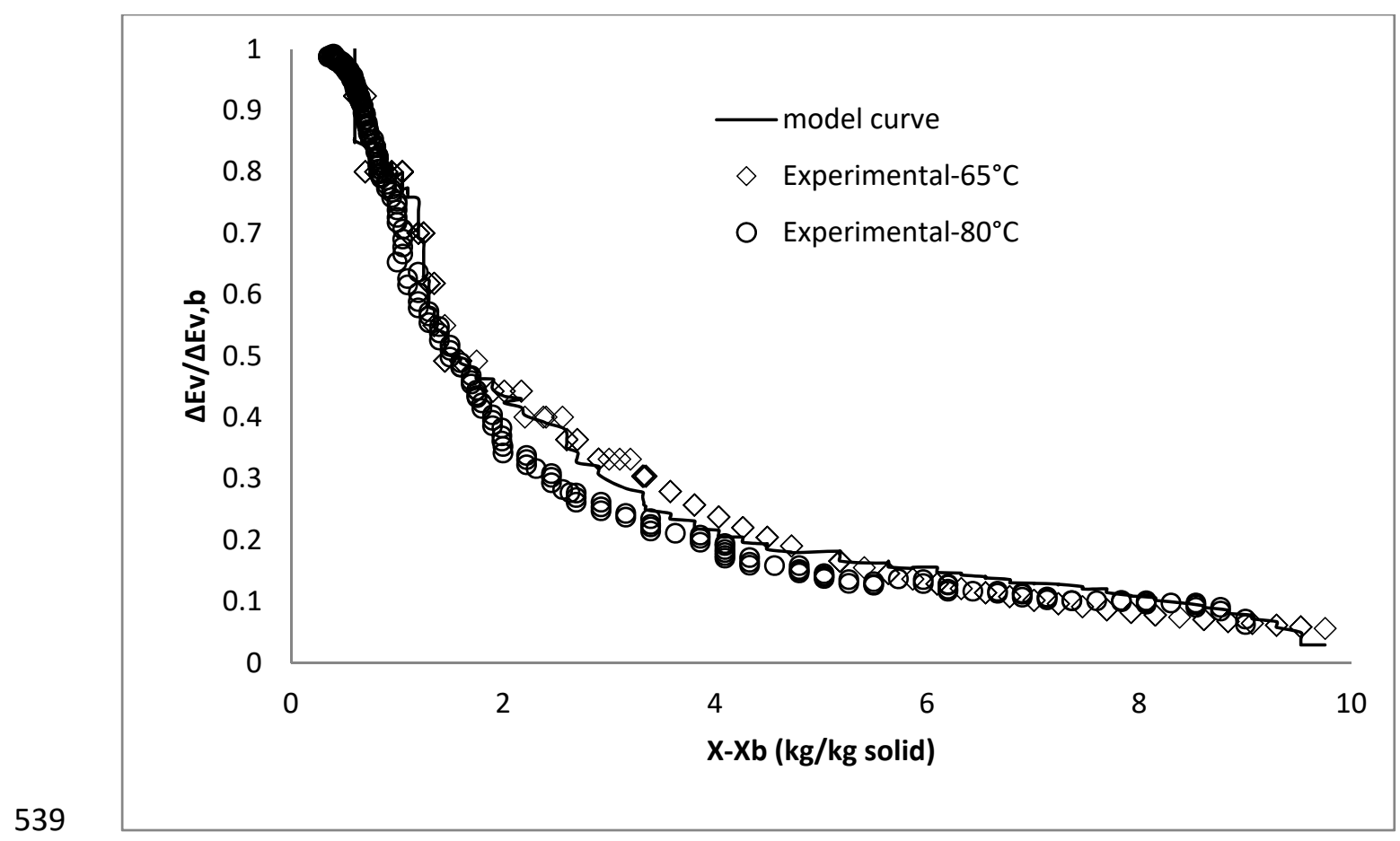

540 Fig. 5. Relative activation energy curves for drying of $\beta-\mathrm{Lg}$ droplets at $65{ }^{\circ} \mathrm{C}$ and $80{ }^{\circ} \mathrm{C}$ 541 drying temperature. 


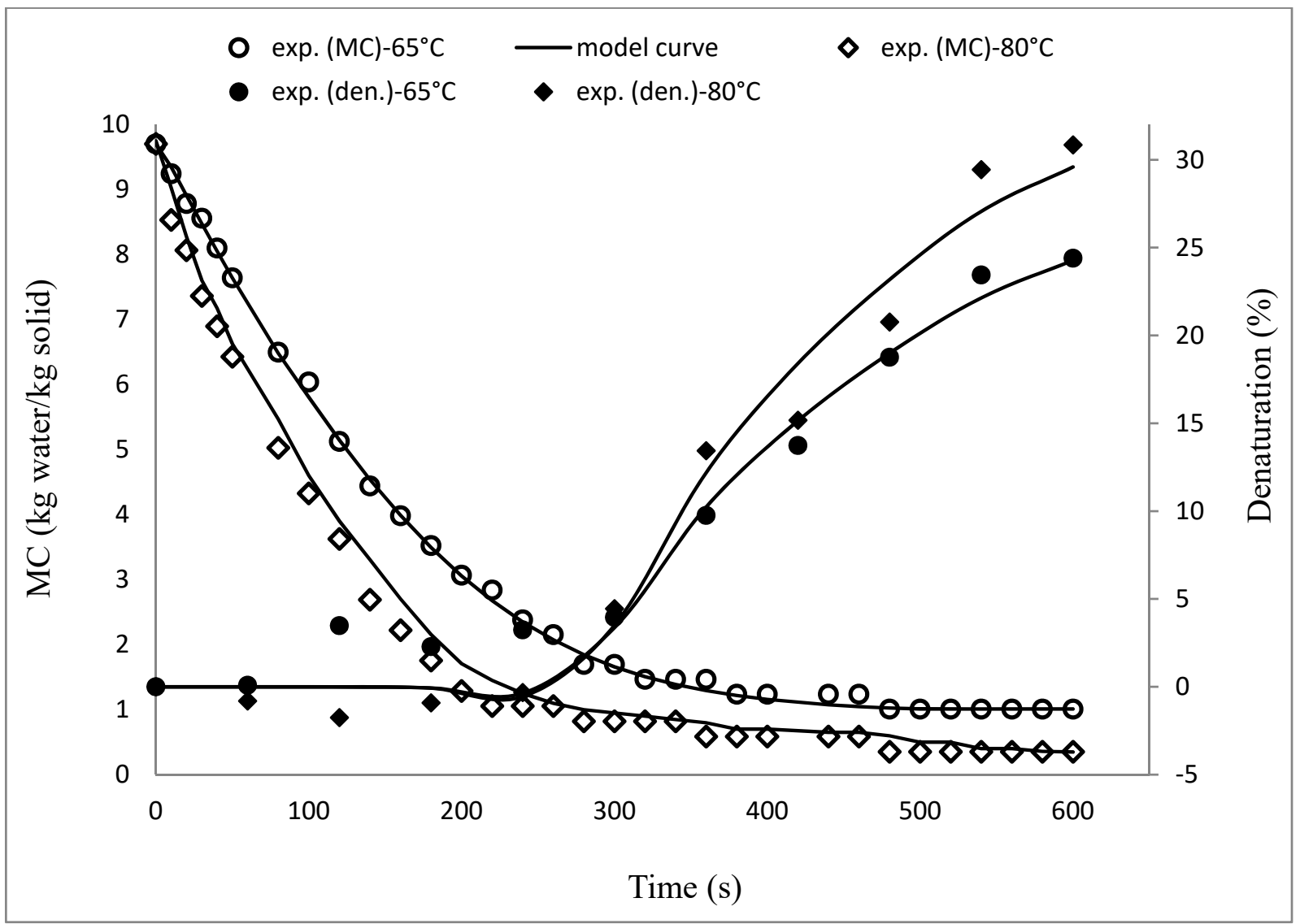

Fig. 6. Experimental and predicted moisture content (MC) and denaturation profiles of $\beta$-Lg during droplet drying at $65{ }^{\circ} \mathrm{C}$ and $80{ }^{\circ} \mathrm{C}$ drying temperature. 


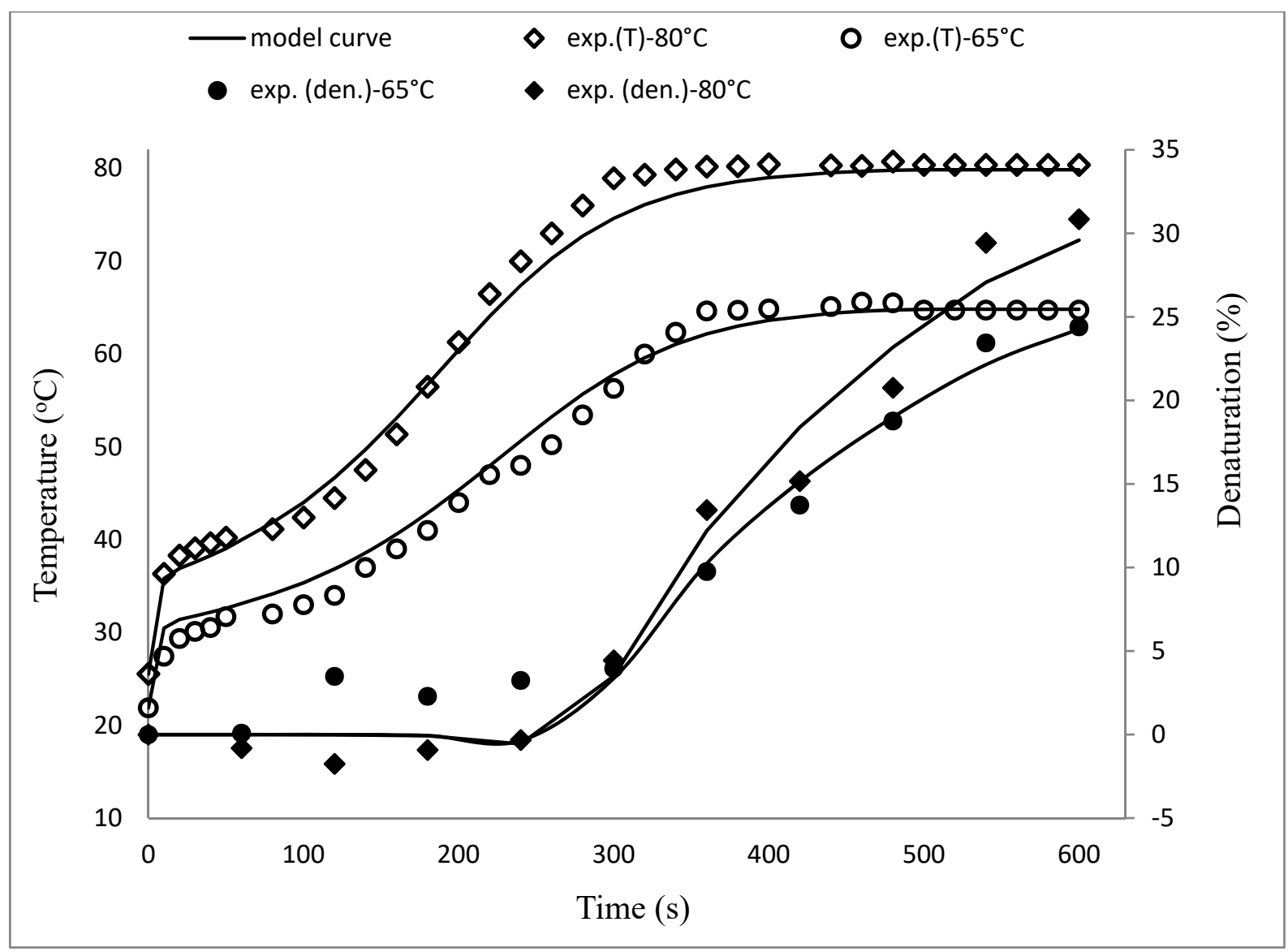

555 Fig. 7. Experimental and predicted droplet temperature (T) and denaturation profiles of $\beta$-Lg 556 during droplet drying at $65^{\circ} \mathrm{C}$ and $80{ }^{\circ} \mathrm{C}$. 


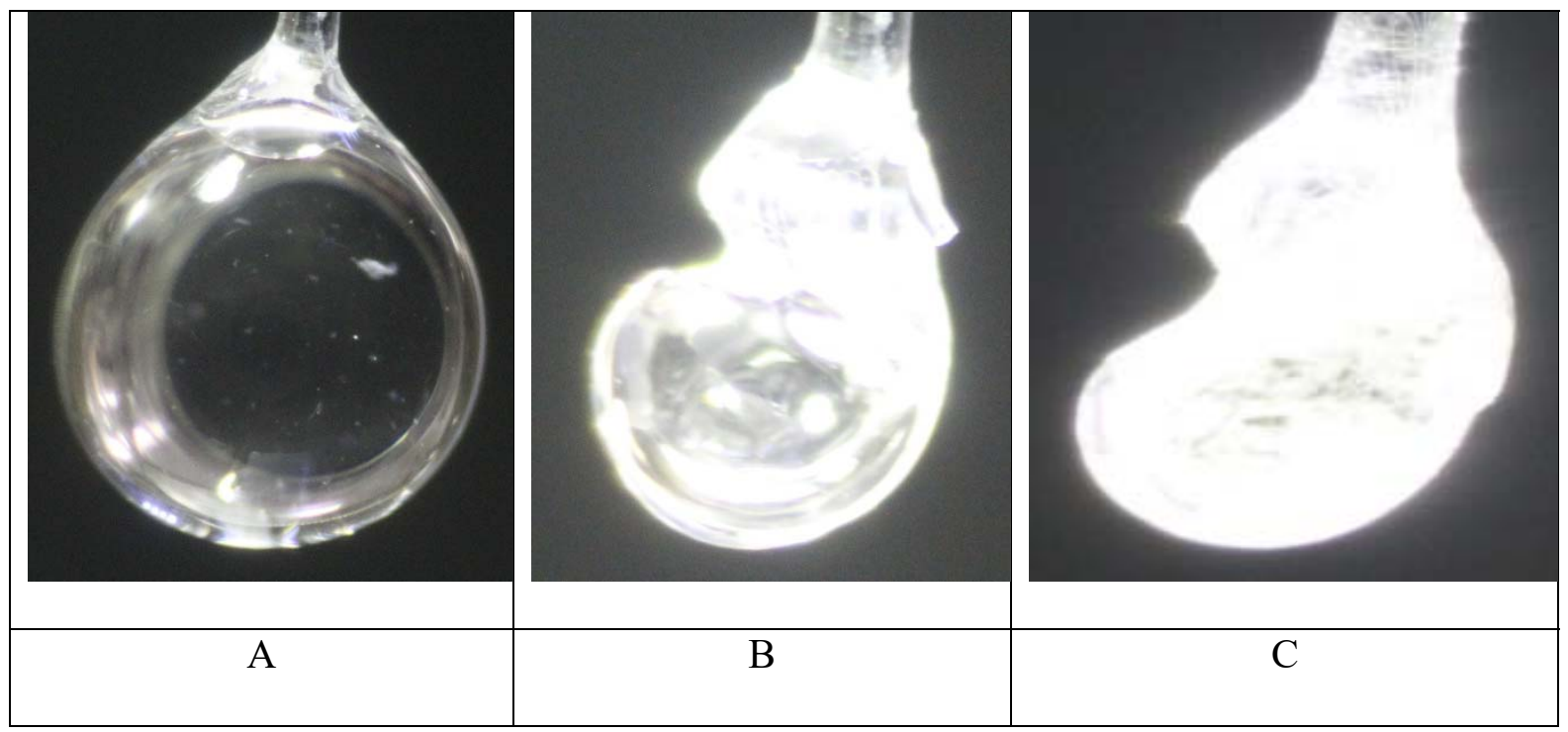

559

560 Fig. 8. Morphology of $\beta$-Lg droplet captured (A) before drying and after drying at (B) $65^{\circ} \mathrm{C}$ 561 and (C) $80^{\circ} \mathrm{C}$. 
564 Table 1

565 The drying conditions during single droplet drying of $\beta-\mathrm{Lg}$

\begin{tabular}{|l|c|c|}
\hline \multicolumn{1}{|c|}{ Experimental conditions } & $65{ }^{\circ} \mathrm{C}$ drying air & $80^{\circ} \mathrm{C}$ drying air \\
\hline Initial temperature $\left({ }^{\circ} \mathrm{C}\right)$ & 23.65 & 24.56 \\
\hline Initial moisture content $(\mathrm{kg} / \mathrm{kg}$ dry solid) & 9.75 & 9.75 \\
\hline Drying air velocity $(\mathrm{m} / \mathrm{s})$ & 0.5 & 0.5 \\
\hline Relative humidity $(\%)$ & $2.5 \pm 0.5$ & $2.5 \pm 0.5$ \\
\hline Initial droplet diameter $(\mathrm{m})$ & 0.002 & 0.002 \\
\hline
\end{tabular}

566

567 Table 2

568 Kinetic parameters in prediction of denaturation of $\beta$ - Lg during droplet drying

\begin{tabular}{|c|c|c|c|c|c|c|}
\hline $\begin{array}{c}\text { Drying } \\
\text { temperature }\end{array}$ & $\mathrm{K}_{\mathrm{o}}\left(\mathrm{s}^{-1}\right)$ & $\mathrm{a}$ & $\mathrm{b}$ & $\begin{array}{c}\mathrm{E} \\
\left(\mathrm{kJ} . \mathrm{mol}^{-1}\right)\end{array}$ & $\mathrm{R}^{2}$ & $\%$ error \\
\hline $65^{\circ} \mathrm{C}$ & 80867 & 306 & 400743 & 56.28 & 0.960 & 5.95 \\
\hline $80{ }^{\circ} \mathrm{C}$ & 79005 & 298 & 354023 & 54.72 & 0.935 & 6.01 \\
\hline
\end{tabular}

569

570 